\title{
The development of artistic creativity in youth in the context of family-related conditions
}

\author{
Marek Swieca dramars@oz.pl \\ Agnieszka Szewczyk \\ Jan Kochanowski University, Kielce, Poland
}

Reference

Swieca, Marek; Szewczyk, Agnieszka; (2012) "The development of artistic creativity in youth in the context of family-related conditions", p. 78-82. In: Barbosa, Helena; Quental, Joana [Eds]. Proceedings of the 2nd International Conference of Art, Illustration and Visual Culture in Infant and Primary Education. São Paulo: Blucher, 2015. ISSN 2318-695X, ISBN: 978-989-98185-0-7

DOI 10.5151/edupro-aivcipe-16

Abstract

Biographical studies make it possible to learn about the memories and experiences connected with the first attempts of artistic creativity of the respondents. They are analyzed in the context of artists functioning within a given family. The data have been gathered by means of psychological tests. During the analysis of the findings the following variables of family life were carefully examined: emotional bonds among the family members, adaWptability of the family system, effectiveness of communication within a family, as well as the educational attitudes of parents seen from the perspective of artists. Learning about the parents' attitude from children's perspective allows one to discover what those children really focus on and how they assess and experience the educational attempts undertaken by their parents. The intensity of the above mentioned factors influencing students in art education programs who are studying fine arts in Kielce has been analyzed.

Keywords artists' biographies, artistic creativity, family-related conditions of creativity

\section{Introduction}

Artistic creativity is a process of changing, processing and creating visual forms (both on surface and in space) and assigning new ideological (mental) attributes to these unfamiliar and original visual forms that are expressed by means of nonmaterial values (ideological, aesthetic) and which are relative material values (Popek, 2010:11).

The initiation and making of these type of changes by an individual in his surroundings always occurs in a specified social context. In search of conditions for creative activity one must then concentrate not only on subject-related factors but also on elements which surpass the individual himself, as the source of factors that influence one's creative effectiveness may be a peer group, family, school, work or - on the widest scale - culture and society (Karwowski, 2009:57). Assuming egalitarian understanding of creativity as a psychological human feature, despite the fact that it may occur on a different level for each individual (Necka, 2003:19), one might suppose that "an individual may use the rightful ability of all people to be creatively active only to the extent to which freedom of social functioning is allowed by others." (Mendecka, 2008:140). Of all the diverse forms of social environment, the family should receive most attention as it is the first and at the same time the most important environment which has the longest lasting influence on an individual and which either fosters or hampers the development of aptitudes. In an analysis of the family environment as a set of outside factors that influence the artistic activity of an individual, a systematic conception of creativity was considered (see Csikszentmihalyi, Kozielecki, S. Popek, Simonton, Sternberg and Lubart). These factors facilitate the understanding of creativity as a result of functioning of an individual (with specified mental and physical predispositions) in a specific environment and culture (Popek, 2001:155). 
2nd International Conference Art, Illustration and Visual Culture in Infant and Primary Education $2^{\circ}$ Congreso Internacional

Arte, Ilustración y Cultura Visual en Educación Infantil y Primaria $2^{\circ}$ Congresso Internacional

de Arte, llustração e Cultura Visual

na Educação Infantil e Primária

Early experiences in the home play a significant role in shaping the personality of future artists. A family environment provides an individual with initial patterns of activity and models of operation as well as presents cultural norms and system of values. The family equips an individual for functioning in repeated contexts of development (Mendecka, 2003:118). Research findings on family experiences of developing creativity of children as presented in subject literature pertain mainly to parental attitudes of parents who shape and establish a specific way of interacting with a child, at the same time exerting influence on shaping his personality. It proves, for example, that parental attitudes of positive nature (accepting the child, being familiar with his needs and interests, wise love without overprotection, reasonable freedom and respect) which are free from autocratism and excessive demands have a particularly stimulating effect on the child (Pufal-Stuzik, 2005:272). Baldwin, Kalhorn and Breese noted significant statistical differences in intellectual development of children depending on the types of attitudes of their parents as children of parents who display a democratic type of behavior exhibit a high degree of originality, planning, persistence, curiosity and fantasy (Ziemska, 2009:36).

It is not easy to determine the real family conditions of creativity and the research results available in the subject literature are ambiguous. In psychology this relates to family socialization of talented individuals and there are two contradictory types of family atmosphere that can determine creative development. On the one hand, there is the atmosphere of acceptance and support for all the efforts made to develop one's talents. On the other hand, there is the negative atmosphere (emotional coldness, distance, hostility, lack of love) (Pufal-Struzik, 2006:79-80). The willingness to forget difficult experiences may produce a great interest in a certain field of art ("escape into creativity") (Necka, 2004:146).

By atmosphere that is conducive to creativity one understands the features of an environment which may be either a stimulus or an inhibitor of creative activity. As M. Karwowski rightly indicates (2009:58), "these attributes are not always an objective characteristic of every place. Quite often they are connected with a subjective evaluation of one's origins of creativity which is conducted by an individual." An analysis of subjective assessment of family functioning by creative individuals becomes particularly important in a situation of contemplating family conditions of creativity since it is what the individual perceives and experiences that seems to have a stronger influence on his activity than an objective description of a real family life. Considering the impact of the variables of family life for developing artistic creativity of an individual, it seems justifiable to assume a system concept of the family. One of the characteristic features of the system is that the elements that make up the whole must interact with each other. Likewise, in every family there are specific patterns of mutual interactions, which when repeated become well-established and determine the behavior of its members (Drozdzowicz, 1997).

Based on the literature review presented above the authors formulated the question concerning the attributes of the family environment as perceived by youth with artistic talent.

\section{The method}

The research study was conducted in a group of 26 art students (art education in fine art) aged 19-23. In the group there are 17 females (65\%) and 9 males (35\%). The development of creative abilities characteristic for this age group occurs in the period of an adult's art (the so called phase of intellectual realism). The artworks at this stage are an artistic expression of the artist's individualism (Popek, 1998:108).

The presented research study aimed to discover the factors that influence the creativity of individuals engaged in creative activity. The art education students meet this requirement since while pursuing the degree in fine art they are required to make artwork using their personal and individual ideas (Mendecka, 2003:121). The aim of the research was therefore to discover the selected areas of functioning of family life as perceived by youth with artistic talent.

The authors decided to combine the qualitative method (biographical research) and quantitative method (a diagnostic questionnaire) in line with the suggestion to combine the qualitative and qualitative approaches in social research as two independent and compatible research endeavors (see triangulation; Drozka, 2010:134). The qualitative scope of the research was achieved through a biographical interview, which as an introspective method allowing for 
$2^{\text {nd }}$ International Conference Art, Illustration and Visual Culture in Infant and Primary Education $2^{\circ}$ Congreso Internacional

A en Educación Infantil y Primaria resso Internacional

de Arte, llustração e Cultura Visual

na Educação Infantil e Primária

reconstruction of the course of personal development of the respondents from childhood to maturing in the profession of an artist. Quantitative data was obtained via psychological tests. The following research tools were used: "Scales of family assessment" (Polish adaptation of FACES IV - Flexibility and Cohesion Evaluation Scale by David H. Olson) as presented by Andrzej Margasinski. The questionnaire consists of 62 statements, which make eight different scales. They may be used to draw conclusions regarding, for example, the cohesion of the family system, its adaptability and communication among the family members as perceived by the respondents. Their task was to assess the truthfulness of the given statements contained in the questionnaire on a five-degree scale (from "I totally disagree" to "I totally agree") (Margasinski 2009); "The scale of parental attitudes" (version M and version O) as created by M. Plopy (version for youth). The scale consists of 75 statements, which all together make 5 attitude scales: Scale I: The attitude of acceptance - rejection, Scale II: the overly demanding attitude, Scale III: The attitude of autonomy, Scale IV, attitude of inconsistency and Scale V: attitude of overprotection. Each of the respondents described the attitude of the mother and father separately based on the assessment of relevance of the set of statements according to the following categories: "true" (5 points), "mostly true" (4 points), "difficult to say" (3 points), "mostly false" (2 points) and "false" (1 point). (Plopa, 2007).

\section{An analysis of the artists' biographies}

Based on the information gathered from the biographical interview we were able to define the characteristics of the course of life of the respondents. The interview included topics such as the importance of family upbringing for development of the respondents. Family upbringing proved to be a crucial factor in student development. Most respondents perceive it as important or very important for their development. Based on the biographical data we also learned the opinions of the authors regarding key individuals in their life. The most valuable sources of support (acceptance, arousing interest, providing a diversity of influences and stimuli in the surrounding, and offering advice in crisis situations) for the respondents proved to be relationships with family members (parents, siblings, aunts, uncles or grandmothers). Occasionally the respondents also mentioned individuals from outside their family circles and daily interactions, namely teachers, peers and friends.

The next topic included in the biographies of the respondents pertained to motives that are conducive to engaging in creative activity. It proved that the creativity of artists is primarily determined and propelled by self-contained rewards such as satisfaction, the joy of creating, the curiosity of seeing the final effect, the willingness to create and to change life, and pursuit of self-development. Some respondents also revealed the need to be socially recognized and to receive feedback from their surrounding concerning the value of their works, which may be a form of affirmation of the life path chosen by them.

As for the goals to be achieved in the future, the respondents most often mention raising their qualifications and gaining education. Moreover, the pursuits of the artists also include travel plans and the desire to explore the world in order to find inspiration for further art or find a satisfying and well-paid job.

The obstacles which they may encounter on their way to achieving these goals mainly include a lack of finances as well as laziness and poor self-discipline. Some respondents also face other difficulties such as family conditions, for example, a lack of family support or a parent's illness. There are certain contradictions in the respondents' opinions which pertain to their situations concerning their creativity. On the one hand, they highly value self-development and yielding to the passion to create. On the other hand, they are hindered by the lack of self-discipline. Likewise, the willingness to pursue one's passion may conflict with the need to finance this endeavor.

\section{The results and analysis of the quantitative research studies}

The intensification of specific parental attitudes in parental behavior as perceived by creative youth is illustrated in Table 1. It proved that a vast majority of the respondents with artistic talent observe parental attitudes in their parents, which are characterized by emotional closeness 
International Conference

Art, Illustration and Visual Culture in Infant and Primary Education de Arte, llustração e Cultura Visual

na Educação Infantil e Primária
Table 1. Parental attitudes of mothers and fathers as perceived by the respondents
Table 2. Characteristics of the family system as perceived by the respondents

\section{A discussion of the results and conclusion}

with their children, flexible behavior which is adapted to fit the developmental needs of their child, respect for the child's beliefs and "privacy" without overprotection or having overly high expectations from the child. Fathers more frequently than mothers were characterized by the respondents as changeable, inconsistent in their behavior in relating to their children.

\begin{tabular}{|c|c|c|c|c|c|}
\hline \multirow{2}{*}{\multicolumn{2}{|c|}{ The degree of intensity of the parental attitudes: }} & \multicolumn{2}{|c|}{ of mothers } & \multicolumn{2}{|c|}{ of fathers } \\
\hline & & $\mathrm{N}$ & $\% *$ & $\mathrm{~N}$ & $\%$ \\
\hline \multirow{3}{*}{$\begin{array}{l}\text { Acceptance- } \\
\text { rejection }\end{array}$} & Close emotional contact with a child & 10 & 38.5 & 11 & 42 \\
\hline & Average intesity of acceptance & 10 & 38.5 & 10 & 38.5 \\
\hline & Lack of acceptance & 6 & 23 & 5 & 19.5 \\
\hline \multirow{3}{*}{ Autonomy } & $\begin{array}{l}\text { Highly desirable treatment of a child's } \\
\text { independence }\end{array}$ & 12 & 46 & 9 & 34.5 \\
\hline & Average intensity of autonomy & 8 & 31 & 14 & 54 \\
\hline & Lack of autonomy & 6 & 23 & 3 & 11.5 \\
\hline \multirow{3}{*}{ Protection } & overprotection & 5 & 19.5 & 3 & 11.5 \\
\hline & Moderate protection & 9 & 34.5 & 7 & 27 \\
\hline & Balanced attitude & 12 & 46 & 16 & 61.5 \\
\hline \multirow{3}{*}{$\begin{array}{l}\text { Being } \\
\text { demanding }\end{array}$} & Overly demanding attitude & 6 & 23 & 5 & 19.5 \\
\hline & Moderate attitude & 6 & 23 & 10 & 38.5 \\
\hline & Balanced attitude & 14 & 54 & 11 & 42 \\
\hline \multirow{3}{*}{ Inconsistency } & Inconsistent attitude & 4 & 15 & 9 & 34.5 \\
\hline & Moderate attitude & 7 & 27 & 11 & 42.5 \\
\hline & Balanced attitude & 15 & 58 & 6 & 23 \\
\hline
\end{tabular}

*Note that the percentage was calculated based on $\mathrm{N}=26$ respondents.

The analysis of the empirical material has facilitated defining the level of cohesion and flexibility of the family system as experienced by the respondents (the ability to change its leadership, roles and the principles of mutual relationships), and assessing the communication skills used by a given family system. The obtained results are presented in Table 2.

\begin{tabular}{llcc}
\hline Characteristics of a family system & $\mathrm{N}$ & $\%^{*}$ \\
\hline \multirow{2}{*}{$\begin{array}{l}\text { Levels of balanced } \\
\text { cohesion }\end{array}$} & Strong bonds & 12 & 46 \\
\cline { 2 - 4 } & Medium bonds & 8 & 31 \\
\cline { 2 - 4 } $\begin{array}{l}\text { Levels of balanced } \\
\text { flexibility }\end{array}$ & Weak bonds & 6 & 23 \\
\hline \multirow{2}{*}{ Family comm flexibility } & 11 & 23 \\
\cline { 2 - 4 } & Average flexibility & 9 & 42.5 \\
\cline { 2 - 4 } & Low flexibility & 10 & 40 \\
\cline { 2 - 4 } & Very good communication & 11 & 44 \\
\cline { 2 - 4 } & Average communication & 4 & 44 \\
\hline
\end{tabular}

"Note that on the "family communication" seale, the pereentage was calculated based on $\mathrm{N}=25$ respondents due to the lack of data from one individual.

The presented data indicate emotional closeness between the individual members of the family systems of the respondents. Moreover, according to the respondents, these families tend to have an average level of flexibility in adapting to changes and a diverse level of effectiveness of communication between family members (the results concerning good communication and poor communication between the family members are similar).

According to the research findings the relationships with family members are an important area of interaction of artists with individuals who are key in the development of their artistic creativity. This is proven by the observations of the respondents revealed in the biographical interview as well as the quantitative analysis of the collected empirical data. K. Lasocinska 
2nd International Conference Art, Illustration and Visual Culture in Infant and Primary Education
Congresso Internacional

de Arte, llustracão e Cultura Visual

na Educação Infantil e Primária

(2009:132) drew a similar conclusion with regard to the important and supportive role of the family for development of creativity of an individual based on the analyzed biographies of the graduates from Akademia Sztuk Pieknych in Lodz.

Moreover, the perceptions of youth with artistic talent indicate that parental attitudes were conducive to developing talents of the respondents. There was an atmosphere of family approval determined by the desirable influences as seen from the perspective of proper upbringing. The respondents in G. Mendecka's study (2003:163) were also raised in favorable family environment, in which love dominated over rejection and liberalism over demands.

\section{Summary}

The article describes the characteristics of selected variables of the family environment in which artists are raised. The goal of the study thus has been achieved. The presented research results confirm the thesis that young artists value approval of their works and actions by their family, peers and educators. The respondents are able to plan their goals based on the possessed special and artistic aptitudes. They begin to perceive aesthetic values in the recognized works of art and desire to create works which are valuable. They are willing to choose the difficult path of self-realization. The foundation for these choices was laid for them by their family.

\section{Bibliography}

Drożdżowicz, L. (1997), Ogólna teoria systemów [in:] B. Barbaro (ed.), Wprowadzenie do systemowego rozumienia rodziny (pp. 9-17), Kraków: Collegium Medium UJ.

Dróżka, W. (2010), Triangulacja badań. Badania empiryczne ilościowo - jakościowe [in:] S. Palka (ed.), Podstawy metodologii badań w pedagogice (pp. 124-135), Gdańsk: GWP.

Karwowski, M. (2009), Klimat dla kreatywności. Koncepcje, metody, badania, Warszawa: Difin.

Lasocińska, K. (2009), Badania biograficzne twórców. Rola twórczości w kształtowaniu życia [in:] K. Szmidt (ed.), Metody pedagogicznych badań nad twórczością. Teoria i empiria (pp. 105-146), Łódź: Wydawnictwo AHE.

Margasiński, A. (2009), Skale oceny Rodziny, Warszawa: PTP.

Mendecka, G. (2003), Środowisko rodzinne w percepcji osób aktywnych twórczo, Częstochowa: Wydawnictwo WSP.

Mendecka, G. (2008), Rodzina jako środowisko stymulujące twórczą aktywność jednostki [in:] I. Pufal - Struzik, T. Giza, (ed.), Dyspozycje twórcze i zdolności: wybrane zagadnienia pedagogiczne i psychologiczne. Studia Pedagogiczne Uniwersytetu Humanistyczno - Przyrodniczego (Tom 17, pp. 139-144), Kielce: Wydawnictwo UHP Jana Kochanowskiego.

Nęcka, E. (2003), Psychologia twórczości, Gdańsk: GWP.

Plopa, M. (2007), Psychologia rodziny: teoria i badania, Kraków: OW „Impuls”.

Popek, R. (1998), Z badań nad uzdolnieniami plastycznymi młodzieży. Analiza psychologiczna, Lublin: Wydawnictwo UMCS.

Popek, S. (2001), Człowiek jako jednostka twórcza, Lublin: Wydawnictwo UMCS.

Popek, S. (2010), Psychologia twórczości plastycznej, Kraków: OW „Impuls”.

Pufal-Struzik, I. (2005), Wzmacnianie twórczego rozwoju dziecka w rodzinie [in:] K. Gąsior, T. Sakowicz (ed.), Pedagogika społeczna w służbie rodzinie: (aspekt marginalizacyjny, resocjalizacyjny i psychologiczny) (pp. 267-274), Kielce: ŚCPiE.

Pufal-Struzik, I. (2006), Podmiotowe i społeczne warunki twórczej aktywności artystów, Kielce: Wydawnictwo WŚ.

Ziemska, M. (1973, 2009), Postawy rodzicielskie, Warszawa: Wydawnictwo Wiedza Powszechna. 